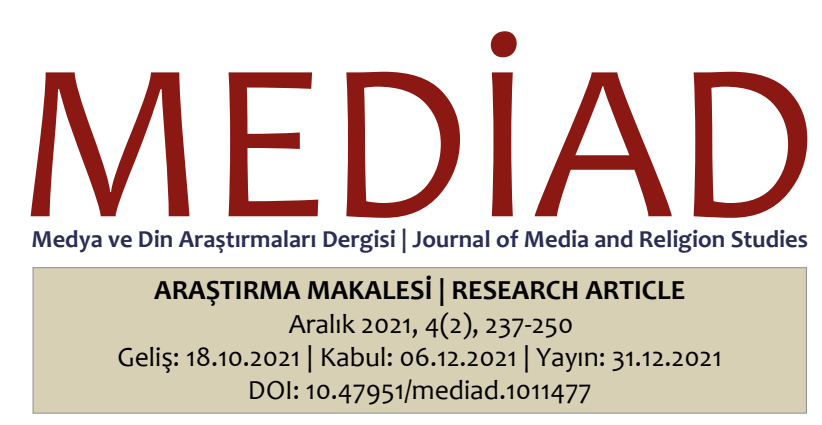

\title{
“Makul”ü Öldürmek: Kalifat Dizisinde Müslüman Kimliğinin Temsili
}

\author{
Şükrü BALCI* \\ Muhammet Emin ÇiFçi**
}

Öz

İslam'a ve Müslümanlara yönelik temelsiz bir korku ve düşmanlık halini ifade eden İslamofobi, Avrupa'da aşırı sağın yükselişine paralel olarak şiddetini artırmaktadır. Özellikle 11 Eylül saldııları sonrası İslam'a ve Müslümanlara sürekli olarak olumsuz temsillerle yer veren Batı medyası, İslamofobinin güçlenmesine ve bunun bir sonucu olarak Batı'da yaşayan Müslümanların İslamofobik gruplar için bir hedef haline gelmesine yol açmıştır. İslamofobi'nin tırmanışa geçmesinde diğer medya araçları kadar sinema filmleri ve diziler de etkili olmuştur. İsveç yapımı Kalifat (Hilafet) dizisinde Müslüman kimliğinin nasıl temsil edildiğine odaklanan bu çalışmada, söylemin arkasında gizli yapıları ortaya çıkarabilmek ve Müslüman kimliğinin ne şekilde inşa edildiğini ortaya koyabilmek amacıyla söylem analizi yöntemi kullanılmıştır. Çalışmanın sonucuna göre, dizide Müslüman yahut Müslüman kökenli karakterler iki aşırı uçta temsil edilmiştir. Batılı değerleri sahiplenen, asimile olmuş seküler göçmen kimliğinin karşısına “makul” bir dindar kimliği değil, ışiD terörüne destek verecek denli radikal bir dindar profil yerleştirilmiştir. Dindar olarak temsil edilen karakterlerin tamamı IşiD destekçisi olup "ortalama” bir dindar kimliğiyle hayatını sürdüren hiçbir karakter yoktur. Buna paralel olarak dizide ışīD’i desteklemeyen Müslüman kökenli karakterlerin tamamı son derece seküler yaşamlarla temsil edilmişlerdir. Bu anlamda, Kalifat dizisinin tasavvurundaki İsveç’te sıradan bir dindar Müslüman'a yer yoktur. Dindarlığı radikalleşme ve terörizmle eşdeğer şekilde sunan dizi, böylelikle İslamofobinin yeniden üretilmesine aracılık etmiştir.

Anahtar Kelimeler: Medya, Temsil, i̇slamofobi, İsveç, Kalifat

\section{Killing the "Average": Representation of Muslim Identity in Kalifat}

\begin{abstract}
Expressing an unfounded fear and hostility towards Islam and Muslims, Islamophobia is gaining strength in parallel with the rise of the far right in Europe. Especially after the September 11 attacks, the Western media, which constantly included Islam and Muslims with negative representations, led to the strengthening of Islamophobia and as a result, Muslims living in the West became a target for Islamophobic groups. In this study, which focuses on how the Muslim identity is represented in the Swedish TV series Kalifat, the method of discourse analysis is used to reveal how the Muslim identity is constructed. According to the result of the study, Muslim or Muslim-origin characters were represented at two extremes in the series. Instead of an "average" religious identity, a religious profile that is radical enough to support ISIS terrorism is placed against the assimilated secular immigrant identity that embraces Western values. All of the characters represented as religious are supporters of ISIS, and there is no character who lives with an "average" religious identity. Parallel to this, all of the Muslim-origin characters who do not support ISIS in the series are represented by extremely secular lives. In this sense, there is no place for an ordinary devout Muslim in Sweden in the imagination of the Kalifat series. Presenting religiosity as equivalent to radicalization and terrorism, the series thus mediated the reproduction of Islamophobia.
\end{abstract}

Keywords: Media, Representation, Islamophobia, Sweden, Kalifat

ATIF: Balcı, Ş. ve Çifçi, M. E. (2021). “Makul”ü öldürmek: Kalifat dizisinde Müslüman kimliğinin temsili. Medya ve Din Araștırmaları Dergisi (MEDiAD), 4(2), s. 237-250. 


\section{Giriş}

Amerika Birleşik Devletleri ve Avrupa'da aşırı sağın yükselişiyle beraber İslamofobi de ivme kazanmış durumdadır. Müslümanlara yönelik ayrımcılık ve nefret söylemine yol açan İslamofobi psikolojik şiddetle sınırIı kalmamakta, Christchurch saldırısı örneğinde olduğu gibi birçok Müslümanın katledildiği terör eylemlerine de neden olmaktadır. Özellikle Avrupa'da Müslümanlar giderek daha güvensiz bir yaşam sürmekte, evlerinde, sokaklarında, camilerinde İslamofobik terörün hedefi haline gelebilmektedirler. ${ }^{1}$

İslamofobi'nin güç kazanmasında birçok nedenle beraber medya da etkili olmuştur. Özellikle 11 Eylül sonrası yaptığı haberlerle İslam'ı ve Müslümanları terörle özdeșleștiren Batı medyası, İslamofobi'nin üretilmesinde en etkin araç olarak değerlendirilmektedir. Bununla birlikte İslamofobi'nin üretimi yalnızca haber medyasıyla sınırlı olmayıp diğer medya ürünleri de bu amaçla kullanılmaktadır (Gölcü ve Çuhadar, 2017) Sahip oldukları etki alanının büyüklüğüyle sinema filmleri ve diziler de İslamofobik söylemin yeniden üretilmesinde etkin şekilde kullanılan araçlardır. Özellikle Hollywood sinemasının, İslamofobinin yeniden üretilmesi ve dolaşıma sokulmasında oynadığı rol, birçok çalışmaya konu olmuştur (Arvas, 2016; Demir, 2020; Ekinci, 2014; Kiran, Qamar, Adnan ve Youssef, 2021; Sevimli ve Kasım, 2019; Uluç ve Küngerü, 2018; Yel, 2018; Türkmen ve Özçınar, 2020).

Sinema filmleri ve dizilerin bireylerin kimlik oluşum süreçlerinde oynadığı rol, temsil sorununu bu platformlar için hayati bir mesele haline getirmektedir. İslam'a ve Müslümanlara dair bildiklerini medya dolayımıyla öğrenen bir Avrupalı için film ve dizilerde sürekli olarak olumsuzluklarla temsil edilen Müslümanlar doğal bir "öteki" olacaktır. Çalışmada ele alınan Kalifat (Hilafet) adlı dizi İsveç yapımıdır. İsveç, İslam karşıtı aşırı sağ partilerin yükselişe geçtiği, Müslümanlara yönelik İslamofobik saldırıların artışta olduğu Avrupa ülkelerindendir. Bu nedenle Müslüman karakterlerin merkezde olduğu İsveç yapımı bir dizide Müslüman kimliğinin nasıl temsil edildiği konusu büyük bir öneme sahiptir.

Kalifat adlı dizide Müslümanların nasıl temsil edildiğini inceleyen bu çalışmanın ilk bölümünde temsil kavramı üzerinde durulacak, ikinci bölümünde ise İslamofobi kavramı ve onun medya temsilleriyle ilişkisi ele alınmıştır. Çalışmanın üçüncü bölümünde i̇sveç’te İslamofobi konusu incelenecek, uygulama bölümünde ise Kalifat dizisindeki Müslüman temsilinin ne şekilde inşa edildiğinin ortaya konulabilmesi için söylem analizine başvurulmuştur.

\section{Medya ve Temsil}

Gerek geleneksel gerek yeni medya araçlarının gündelik hayatta bu denli merkezi bir konuma oturduğu günümüzde, medya ve temsil ilişkisi belki de hiç olmadığı kadar önem kazanmış durumdadır. Medya ve temsil konusunu iletişim çalışmalarının gündemine sokan İngiliz Kültürel Çalışmaları ekolünün önde gelen isimlerinden Stuart Hall'ün düşüncesinde temsil, dil ve kültür arasında güçlü bir bağ bulunmaktadır. Hall'e (2003) göre «bir temsil sistemi» olan dilde, hangi türden olursa olsun şeyleri temsil etmek için çeşitli sembol ve işaretler kullanılmaktadır. Dilin bu anlam inşa edici özelliği onu «bir kültürde düşüncelerin, fikirlerin ve duyguların temsil edildiği “'araç’lardan biri" haline getirir ve tam da "bu nedenle dil aracılığıyla temsil, anlamın üretildiği süreçlerin merkezinde yer alır” (Hall , 2003, s. 1).

Hall ile benzer şekilde Polat (2018, s. 48) da temsili, "olaylara, olgulara ilişkin zihinsel algılamalarımızın dil ile olan ilişkisi neticesinde ortaya çıkan bir anlamlandırma süreci" olarak tanımlamaktadır. Kavrama daha iletişimbilimsel perspektiften yaklaşan Price’a göre ise temsil, "sosyal grupların, farklı alt kültür, meslek, yaş, sosyal sınıf ve mekanların medyada gösterilme şeklini ve bu gösterilme şeklinin izleyiciler tarafından nasıl yorumlandığını anlatmaktadır" (akt.: Söğüt, 2019, s. 214). Varol (2014, s. 309), medyada yer alan temsillerin, "gerçekliğin yansıması değil, yeniden inşa edilmiş ve zaman zaman çarpıtılmış biçimleri" olduğunu söylemektedir. Bu bağlamda medyada yer alan temsiller manipülatif ve genellikle ideolojiktir.

Medya, gerçekleșen bir olayın hangi boyutunun seyirciye gösterilip hangi boyutunun gizleneceğine, söz konusu olayın nasıl bir dil kullanılarak aktarılacağına karar vermekte, bu bağlamda izlerkitleyi yönlendirmektedir (Yel, 2018). Medya kuruluşları politik yahut ekonomik çıkarlarının şekillendirdiği kimlik politikalarına göre belli bir toplumsal grubu ön plana çıkarırken farklı bir grubun üstünü örtebilmekte yahut bunlara dair yanlış temsillere yer verebilmektedir (Varol, 2014). Medya, yer verdiği temsillerle kişilerin birtakım toplumsal gruplara karşı sahip olduğu algııı şekillendirmekte, zamanla bu algılar birer "toplumsal gerçeklik" halini almaktadır (Deniz, 2010). Temsil yoluyla insanlara belirli kalıplar sunulmakta, izlerkitlenin kendisine, ötekine ve olaylara nasıl bakacağı şekillendirilmektedir (Söğüt, 2019).

Medya temsilleri ile bireylerin kimlik oluşumları arasında da güçlü bir ilişki bulunmaktadır. Medya, sunmuş olduğu temsillerle belirli kimlik özelliklerini model olarak ortaya koyarak bireylerin kimliklerinin şekillenmesinde aktif bir rol oynamaktadır (Varol, 2014). Bununla birlikte medya, bireylerin kimlik oluşum süreçlerin- 
de "biz"in ve "öteki"nin tanımlanmasında da etkili olmaktadır (Posos Devrani, 2017). İnsanlar takip ettikleri medya içerikleri tarafından birtakım stereotiplere dönüştürülmeye çalışılmaktadır (Yel, 2018). Bu anlamda, medya temsillerinin toplumsal sonuçları olduğu gibi bireysel/psikolojik sonuçları da vardır.

Temsil probleminin kendini gösterdiği medya türlerinden biri de sinema filmleri ve dizilerdir. Uluç ve Küngerü (2018, s. 1), sinemayı "temsil politikalarının uygulama alanı bulduğu en önemli mecralardan biri olarak” değerlendirmektedir. Sinema, başlangıcından itibaren izlerkitleyi yönlendirerek mevcut sistemin devamını sağlamak yahut onu dönüştürmek gibi amaçlarla kullanılagelmiştir (Sevimli \& Kasım, 2019). Medyada yer alan temsillerin egemen ideolojiye göre/egemen ideoloji tarafından şekillendirildiği (Göker ve Keskin, 2015) düşünüldüğünde, egemen ideolojinin dışında kalan dezavantajlı grupların sinema filmlerinde ve dizilerde nasıl temsil edildiği sorunu önem kazanmaktadır. Posos Devrani’nin (2017) vurguladığı gibi, sahip olduğu etki alanının büyüklüğü nedeniyle medyanın -özellikle de televizyon yapımlarının- dahil olduğu bir ayrımcılık, ilgili kişi ya da toplumsal gruplara yönelik önyargılar oluşmasında son derece etkilidir. Bu nedenle özellikle aşırı sağın ve İslamofobinin yeniden yükselişe geçtiği Avrupa'da, başta Müslümanlar olmak üzere Batılı değerlerin ve yaşam tarzının dışında kalan toplumsal grupların sinema filmleri ve dizilerde nasıl temsil edildikleri son derece kritik bir konu olarak ortaya çıkmaktadır.

\section{2. İslamofobik Temsillerin Medya Içceriklerine Yansıması}

Başta Batı'da yaşayan Müslümanlar olmak üzere İslam dünyasının bütününü tehdit eden bir olgu olarak İslamofobi, özellikle Soğuk Savaş sonrası sistematik bir biçimde şiddetini artırmıştır. İslamofobi kavramı, İngiltere'de İslamofobi'ye yönelik gerçekleştirilen geniş çaplı bir çalışma olan The Runnymede Trust (1997, s. 4) raporunda “İslam’a karşı temelsiz düşmanlık” olarak tanımlanmaktadır. İslamofobi’yi bir tür "modern hastalık" olarak değerlendiren Buehler (2014, s. 135) de olguyu, “akli temeli olmaksızın İslam'dan/Müslümanlar'dan korkmak" olarak tanımlamaktadır. Temel'e (2019) göre ise İslamofobi, “íslam dinine ve Müslümanlara karşı duyulan ön yargıya ve ayrımcılığa dayalı korkuyu ifade etmektedir” (s. 94). Gölcü ve Çuhadar (2017), İslamofobi'yi Müslümanlara yönelik olumsuz tutum ve yargıların bütünü olarak değerlendirmektedir. Diğerlerinden farklı olarak Halliday (1999) ise söz konusu durumu doğru şekilde ifade eden kavramın İslamofobi değil "anti-Muslimism” (Müslüman karşıtlığı) olduğunu düşünmektedir. Ona göre bir din olarak İslam'a yönelik düşmanlık Haçlı Savaşları döneminde kalmış olup güncel olarak gözlenen durum Müslüman karşıtlığıdır. Halliday’ın bu tezini savunmak için ortaya attığı kimi önermeler geçerli gözükse de -örneğin aslında son derece seküler bir devlet olan Saddam dönemi Irak'ına yönelik “islamofobik” saldırılar- bir bütün olarak değerlendirildiğinde Müslüman karşıtığını İslamofobi'den ayırmak çok mümkün görünmemektedir. Bunda, bir kavram olarak İslamofobinin Müslüman karşıtlığını da içermesi kadar, Müslüman karşıtlığının düşünsel temellerini İslamofobi'den alması ve günümüzde Müslüman karşıtlığı ile bilinen Avrupalı birçok sağ politikacının bir inanç olarak İslam'ı da hedef almaları² etkilidir. López'e (2011) göre de İslamofobi kavramı, Müslümanların dini yahut etnik temelli olarak tanımlanmalarından bağımsız olarak İslam’a ve Müslümanlara yönelik düşmanca tutumlara işaret etmek için kullanılmalıdır.

İslamofobi’yle ilgili özellikle Batılı literatürdeki çalışmalar, İslamofobi’nin doğuşu için Soğuk Savaş sonrasını yahut 11 Eylül saldırılarını işaret etse de İslam'a yönelik nefret, Batı'nın İslam’la ilk karşılaştığı tarihlere kadar götürülebilmektedir. Soğuk Savaş sonrası Amerika öncülüğündeki Batı cephesinin kendine yeni düşman olarak İslam'ı seçmesi ve 11 Eylül saldırıları sonrası medyada İslam'ın terörle ilişkilendirilmesi İslamofobi'yi doğuran olaylar olmaktan çok onu güçlendiren etkenlerdir. Sonuçta, Hıristiyan dünyasında İslam'a yönelik bir düşmanlık söz konusu olmasaydı, medyanın tek başına bunu doğurması da mümkün olmayacaktı (Buehler, 2014).

Bununla birlikte İslamofobi’nin bu denli yükselişe geçmesinde medyanın büyük bir rol oynadığı da yadsınamaz bir gerçektir. Doğu'nun hep başkalarınca temsil edilen bir olgu olduğunu vurgulayan Yel'e (2018) göre, geçmişte oryantalistlerin yaptığı işi bugün medya profesyonelleri devralmıștır. Jack G. Shaheen'in Hollywood'da Arap ve Müslüman imgesi üzerine yaptığı çalışma, bu tezi çarpıcı biçimde doğrulamaktadır. Söz konusu çalışmada Shaheen (2003), 100 yılı aşkın bir zaman aralığında üretilen 900'ün üzerinde Hollywood yapımını incelemiş, bu yapımların neredeyse tamamında Arapların "kalpsiz, vahşi, barbar” gibi kötü biçimlerde temsil edildiğini ve yalnızca yüzde beşinde normal bir Arap karaktere yer verildiğini ortaya koymuştur.

Gölcü ve Çuhadar (2017), medyayı İslamofobi'nin üretilmesinde en önemli araç olarak değerlendirmektedir. Özellikle 2000 sonrası Batı medyasında Müslümanlar giderek daha olumsuz şekilde temsil edilmeye başlanmış (Sarı ve Klein, 2020), öyle ki Müslüman beden Hollywood'da "tehlikeli, modern öncesi ve medeniyetsiz" olarak inşa edilmiştir (Aguayo, 2009). Benzer şekilde Reid (2015, s. 95) de 11 Eylül saldırılarından 2007'ye kadar olan süreçteki Hollywood yapımlarında Müslüman teröristlerin "dini radikalizm tarafından terör eylemleri gerçekleştirmek üzere ayartılmış sempatik bireyler olarak" kurgulanırken, 2007 sonrası "şiddet içeren eylemlerin gönüllü katılımcıları olarak” resmedildiğini vurgulamaktadır. Soğuk Savaş ve 11 Eylül sonrası 
Amerika öncülüğündeki Batı bloğunun hedefine İslam ve Müslümanlar oturmuş, Hollywood da İslam’ı terörle özdeşleştiren yapımlarıyla bu savaşa destek olmuştur (Fatima, 2016). Buehler (2014) de Batı medyasının özellikle İslam ile terör arasında bir ilişki kurma çabası içerisinde olduğunu söylemektedir. Ona göre, içerisinde Müslüman bir aktörün yer aldığı herhangi bir olayda failin dini kimliği ön plana çıkarılırken farklı dinlerden ve coğrafyalardan kimselerin din adına yaptığı şiddet eylemleri ile o dinin mensupları arasında bir ilişki kurulmamaktadır. Kabir'e (2006) göre medya, İslami militanizm temelinde kurguladığı temsiller yoluyla "tüm Müslümanları etkili bir şekilde şeytanlaştırmıştır" (s. 326). Müslümanların bu şekilde "şeytanlaştırılması", Afganistan ve Irak örneklerinde olduğu gibi, onlara yönelik saldırıları meşrulaştırmıştır (Oumlil, 2009).

Temel ve Koçak (2020, s. 193) ise, çalışmalarında Avrupa medyasının İslam ve Müslümanlarla ilgili içeriklerinin “islam'ın ve Müslümanların baskıcı, şiddet taraftarı olduğu ve Müslümanların toplumsal yapı için bir tehdit unsuru olduklarına yönelik anlatımlar içerdiği; Avrupa'nın İslam ve Müslüman tehdidine karşı dikkatli olması gerektiği ve Müslümanlara yönelik ötekileştirici, kutuplaştırıcı ve ırkçılığa da sebep olabilecek söylemlerin kurgulandığı" sonucuna ulaşmıştır. İtalya ve İspanya medyası üzerine yaptıkları çalışmada Cervi, Tejedor ve Gracia (2021) da bu ülkelerin medyalarında Müslümanların temsilinin İslamofobik saiklerle inşa edildiğini ortaya koymuştur. Ahmed ve Matthes (2017) ise 2000-2015 yılları arasında yayımlanan 345 makaleyi ele aldıkları meta-analizde Batı medyasında İslam'ın şiddetle ilişkilendirilerek, Müslümanların ise olumsuzluklar üzerinden temsil edildiğini tespit etmişlerdir.

\section{3. İsveç'te İslamofobinin Durumu}

Avrupa ülkelerinde yapılan geniş çaplı bir araştırmanın sonucuna göre, bu ülkelerde yaşayan Müslümanlar çeşitli türden ayrımcılıklarla karşılaşmakta olup, kendilerine yönelik fiziki saldırılara da açık bir haldedirler (European Monitoring Centre on Racism and Xenophobia, 2006). Yardım'a (2017) göre 1. Dünya Savaşı sonrası Yahudileri hedef alan Avrupa aşırı sağının hedefine günümüzde Müslümanlar oturmuş; birçok farklı Avrupalı sağ partiden, Müslümanların sınır dışı edilmesi, Müslüman göçmenlerin ülkeye girişinin engellenmesi gibi İslamofobik öneriler getirilmiştir. Bu tür İslamofobik önerilerin politik söylem içerisindeki görünürlüğünün artması, Müslümanlara yönelik olumsuz kanaatlerin yerleşmesinde de etkilidir. Örneğin Danimarka'da yapılan bir çalışmaya göre ülkedeki her dört Danimarkalıdan biri Müslüman göçmenlerin Danimarka'yı terk etmesi gerektiğini düşünmektedir (Reiermann ve Andersen, 2019).

Almanya'da yalnızca 2019 yılında Müslümanlara karşı işlenen ve bir kısmı fiziksel saldırıları da içeren 871 nefret suçu polise bildirilmiş, camilere yönelik saldırılarla mücadele eden Brandeilig adlı organizasyona göre ülkedeki camiler 122 kez saldırıya uğramıştır (Bayraklı, 2020). Fransa'da İslam'ın doğrudan terörle eşdeğer şekilde sunulmasıyla nefret suçuna en çok maruz kalan toplumsal grup Müslümanlar olmuştur (Akgül Durakçay ve Güneş Gülal, 2017). Bir diğer Avrupa ülkesi olan Belçika'da da Müslümanlar hayatın birçok alanında ayrımcılığa maruz kalmakta, Müslümanlara yönelik İslamofobik saldırılar artış göstermektedir (Aydın ve Yardım, 2007). Birçok Avrupa ülkesinde beyaz üstünlükçü, İslam karşıtı gruplar tarafından Müslümanları hedef alan terör faaliyetleri düzenlenmektedir (Bayraklı ve Hafez, 2020).

Çalışmada ele alınan Kalifat dizisinin yayımlandığı İsveç’te de Müslümanlara yönelik saldırıların artışta olduğu bilinmektedir. İsveç Suç Araştırması'na göre 2016 yılında İslamofobik saiklerle işlenen 439 nefret suçu kayıtlara geçmiştir (Bayraklı ve Hafez, 2018). Yalnızca 2017 yılında ülkede çok sayıda camii ve İslam merkezi kundaklama, taşlama, vandalizm gibi saldırılarla karşılaşmış, Müslümanlara ait bir anaokulunun camları kırılmış ve duvarlarına İslamofobik grafitiler çizilmiş, Müslüman ve Yahudileri hedef alacak bombalama girişiminden dolayı 3 kişi tutuklanmış, başörtüsü de dahil olmak üzere dini sembollerin yasaklanmasının ayrımcılık olmadığına hükmedilmiş, aşırı sağcı bir parti olan İsveç Demokratları üyesi politikacılarca "Müslümanların insan olmadığı”, ve ülkedeki Müslüman “sorununun” onların hepsine Hıristiyanlığı kabul ettirerek çözülebileceği söylenmiştir (Gardell ve Muftee, 2018). Kurulduğu 1988 yılında Neo-Nazilerle olan bağları nedeniyle yasaklı olan İslam ve Müslüman karşıtı Hıristiyan Demokratları, günümüzde İsveç Parlamentosundaki üçüncü büyük parti konumundadır. Parti, İslam’ı İsveç halkının bir numaralı düşmanı olarak görmektedir (Tomson, 2020). Yapılan çalışmalar, ülkedeki Müslüman kadınların da çok sayıda fiziki ve sözlü saldırıya maruz bırakıldığını göstermektedir (Abdullahi, 2016). 2011 yılında ülkedeki camilerden \%40’ı çeşitli saldırı ve tehditlerle yüzleşirken bu oran 2014 yılında \%66'ya çıkmıştır (Hussain, 2015). Ülkedeki çevrimiçi nefret suçları 2017 ve 2018 yılları arasında ikiye katlanmış olup, bu saldırıların yarısı Müslümanları hedef almaktadır (Altuntas, 2019). Daha yakın bir tarih olan 2020'de İslam karşıtı bir gösteride Kur'an yakılmış, olayın büyümesiyle eylemcilerle polis arasında çatışmalar yaşanmıştır (Riots in Sweden after far-right activists burn copy of Quran, 2020).

Daha önce değinildiği üzere bireyler üzerindeki etkisi son derece güçlü olan medyanın İslamofobi’yi besleyen yayınlar yapması da Batı'da yaşayan Müslümanların İslamofobik gruplar için birer hedef haline gelmesinde etkili olmuştur. Müslümanların medyada olumsuz temsillerle yer almaları yalnızca önyargılara ve dışlayıcı eylemlere neden olmamış; aynı zamanda Gölcü ve Aydın Varol'un (2018) da vurguladığı gibi Müslümanlara yönelik yukarıdaki örneklere benzer birçok fiili saldırının fitilini ateşlemiştir. 


\section{Yöntem}

Diğer medya ürünleri gibi sinema filmleri ve dizilerin de kendilerini üreten kişi, kurum ve şirketlerin politik yahut ekonomik çıkarlarından, sosyo-kültürel arka planlarından, ideolojik konumlanmalarından soyut şekilde ele alınamayacağı düşünüldüğünde, bu ürünlere birer metin olarak yaklaşıp onları inşa eden süreçlerin çözümlenmesi önem kazanmaktadır. İsveç yapımı Kalifat dizisinde yer alan Müslüman temsillerinin sorunsallaştırıldığı bu çalışmada, Teun van Dijk'ın geliştirdiği söylem çözümlemesi modeli kullanılmıştır. van Dijk'a (2006) göre ideolojiler, ancak söylem yoluyla edinilmekte ve yeniden üretilmektedir. Söylem kısaca, "dilsel pratiklerin kullanılma biçimleri" şeklinde tanımlanabilmektedir (Karaduman, 2017, s. 33). van Dijk (1997), dilin kullanımının yalnızca sözlü konuşmayla sınırlı olmayıp gazete, dergi vb. gibi yazılı metinleri de kapsadığını söylemektedir. Ona göre söylem analizinde dili kimin, nasıl, neden ve ne zaman kullandığı önemli sorular olarak belirmektedir. van Dijk (1997) bu bağlamda, söylem çalışmalarının söylemin şu üç boyutuyla ilgilendiğini söylemektedir: "Dilin kullanımı fikirleri ve etkileşimi nasıl etkiler, ya da tam tersi etkileşimin boyutları insanların konuşma biçimlerini nasıl etkiler yahut fikirler dil kullanımını ve etkileşimi nasıl kontrol eder” (s. 2).

Genel olarak söylem analizinde metnin doğrudan kendisi bir söylem olarak görülmekte ve metin ile metni var eden bağlam arasındaki ilişki incelenerek çözümlenmektedir (Türkdoğan ve Gökçe, 2015). Söylem analizi bu anlamda, dilin kullanımıyla metinde yer alan nesnelerin nasıl inşa edildiğine odaklanmakta (Willig, 1999), metindeki ifadelerin düz anlamlarının ötesine geçmeyi hedeflemektedir (Çelik ve Ekşi, 2008). Burr'un (2012) bütüncül tanımıyla söylem analizi “Metnin içinde işleyen ya söylemlerin ya da metnin inşasında kullanılan dilsel ve retorik araçların ortaya çıkarılma..."sıdır. Van Dijk’ın geliştirdiği söylem analizi modeli de aynı şekilde "medya söyleminin gerisindeki toplumsal yapının (güç ilişkileri, değerler, ideolojiler, kimlikler) nasıl dilsel kurgulara dönüştüğü ile ilgilenir” (Çağlar, t.y., s. 205).

Van Dijk'ın haber metinlerinin çözümlenmesinde uyguladığı söylem analizi modeli, makro yapı ve mikro yapı olmak üzere iki bölümden oluşmaktadır. Makro yapı ise kendi içerisinde tematik ve şematik analiz olarak ikiye ayrılmaktadır. Tematik analizde haberin başlığı, girişi ve fotoğrafları; şematik analizde ise durum başlığı altında haberin ana olayının sunumu, sonuçları, ardalan bilgisi ve bağlam bilgisi, yorum başlığı altında ise haber kaynakları ile habere konu olan tarafların yorumları analiz edilmektedir. Söylem analizinin ikinci boyutunu oluşturan mikro yapı ise sentaktik çözümleme, bölgesel uyum, sözcük seçimleri ve haberin retoriği aşamalarını barındırmaktadır (Özer, 2011). Van Dijk'in geliştirdiği söylem analizi modelinin odak noktasını haber metinleri oluştursa da model, konuşmaların, edebi metinlerin yahut sinema filmleri ve dizilerin çözümlenmesinde de sıklıkla kullanılmaktadır. Ekinci (2014), çalışmasında van Dijk'ın ilgili modelini sinema filmlerinin çözümlenmesinde kullanılmak üzere şu şekilde uyarlamıştır:

Tablo 1

\begin{tabular}{|l|l|l|}
\hline Çözümleme Modeli & Kodlar, Anlamlar & Sinemasal Metinler \\
\hline Mikro Yapılar & Sesler, sözcükler, cümle yapıları. & $\begin{array}{l}\text { Filme ait görsel ve işitsel malzeme. (Giriş } \\
\text { sekansı, Jenerik). }\end{array}$ \\
\hline Makro Yapılar & Konu, Tema, Ana tema. & $\begin{array}{l}\text { Filmin öyküsü, karakterler, mekânların } \\
\text { sunumu ve mikro yapılarla ilişkili ideolo- } \\
\text { jik temsiller. }\end{array}$ \\
\hline
\end{tabular}

Çalışmada, daha sistematik bir çözümleme yapabilmek amacıyla bu uyarlama temel alınacak ancak söz konusu yapımda yer verilmediği için jenerik; filmin öyküsü analiz edilirken yer verildiği için ise mekânların sunumu ve mikro yapılarla ilişkili ideolojik temsiller ayrı bir başlık altında ele alınmamıştır. Bununla birlikte, çalışmanın temel sorunu Müslüman karakterlerin temsili olduğundan çözümlemenin odak noktasını da ilgili karakterlerin çözümlenmesi oluşturacaktır.

\section{Bulgular}

\subsection{Dizinin Künyesi}

Yönetmen: Goran Kapetanovic

Senarist: Wilhelm Behrman ve Niklas Rockström

Yapımcı Şirket: Filmlance International AB ve Imaginarium Films

Uluslararası Dağıtımcı: Netflix 
Yayımlanma Tarihi: 12 Ocak 2020

Bölüm Sayısı: 8

\subsection{Mikro Yapılar}

\subsubsection{Giriş Sekansı}

Dizinin giriş sekansında Türk asıllı bir İsveç vatandaşı olup ışiD’e katılarak Rakka'da yaşamaya başlayan Pervin'in dışarıya çıkmak üzere bebeğini hazırladığı sahne gösterilmektedir. Pervin'in bebeğini giydirirken bir yandan İsveç dilinde bir ninni söylemesi, içerisinde yetiştiği kültürden bütünüyle kopmadığını göstermesi açısından önemlidir. Bebeğini de alıp Tine adlı bir diğer İsveç vatandaşı ile Rakka sokaklarında yürümeye başlayan Pervin ve arkadaşının önü IşiD militanlarınca kesilir ve ikili IşiD’in bir “haine” vereceği cezayı izlemeleri için bölgede bulunan diğer kişilerle birlikte cezanın gerçekleştirileceği "camiye” gitmeye zorlanır. Buradan sonra yaşananlar dizinin geri kalanıyla ilgili fikir vericidir. İhanet ettiği öne sürülen kişi gözleri kapalı şekilde bir masaya oturtulur ve IŞiD militanlarından biri megafonla kalabalığa "Bugün buraya, bize ihanet eden ve bizden uzaklaşanlara ne olacağını görmeniz için getirildiniz... . Hainlerin hakkı budur." anonsunda bulunur. Yükselen tekbir seslerinin ardından cezanın infazı gerçekleşir ve ihanetle suçlanan kişinin eli kesilir. Bu noktada diziyi karakterize eden anlardan biri cezanın infazı sırasında Pervin ve arkadaşının verdiği tepkidir. Tine söz konusu olayı görmemek için kafasını diğer yöne çevirmekte, Pervin ise korkulu bir sesle olayın gerçekleşmek üzere olduğu yere doğru bakarak derin derin nefes almaktadır. Bu durumdan her iki İsveç vatandaşının da içerisinde bulundukları durumdan hoşnut olmadıkları ve örgütün eylemlerini bütünüyle içselleştiremedikleri anlaşılmaktadır. Giriş sekansında "hain”in cezalandırılacağı yer olarak caminin gösterilmesi ve el kesme fiilinin tekbirlerle gerçekleştirilmesi de kayda değer bir diğer noktadır. Elbette ki IşiD gerçekte de bu eylemleri İslami söylemlere başvurarak gerçekleştirmiştir ve bu gerçekliğin diziye de yansıması normaldir. Fakat bununla birlikte, ilerleyen bölümlerde değinileceği üzere İslam'ın yalnızca olumsuzluklar üzerinden temsil edilmesi, dizide İslam'ın olduğu gibi yansıtılmaktan çok İslamofobik bir saikle yeniden inşa edildiğini göstermektedir.

\subsection{Makro Yapılar}

\subsubsection{Olay Örgüsü}

Dizi, IşiD’in de facto başkenti Rakka'da yaşayan İsveçli yabancı savaşçılardan oluşan bir grup IŞiD militanının İsveç’te düzenlemeye çalıştığı terör eylemini merkeze almaktadır. Hüsam adlı militanın karısı Pervin, ışiD’e katıldığı için pişmandır ve 4 aylık bebeği Latifa'yla birlikte Rakka'dan kaçıp İsveç'e dönmeye çalışmaktır. Amacına ulaşmak için İsveç Güvenlik Servisi Ortadoğu Bölümü’nde çalışan Fatima Zukic'le iletişime geçen Pervin'e, söz konusu saldırıyla ilgili bilgileri öğrenip ihbar etmesi karşılığında Rakka'dan kurtarılacağı sözü verilmiştir. Zukic tarafından zaman zaman Rakka'da bırakılmakla tehdit edilen Pervin, kendini riske atarak edindiği bilgileri ona aktarmaktadır.

İsveç'te yapılacak saldırıyı koordine etmesi için “Misafir” kod adlı İbrahim Haddad, Rakka'dan İsveç'e geri gönderilmiştir. İsveç’te Jarva Gard adlı lisede öğretmen asistanı olarak çalışan “ibbe”, bir yandan bu lisede okuyan 3 kız öğrenciye örgüt propagandası yaparken diğer yandan çeşitli sahte kimliklerle eylem için hazırlıklar yapmaktadır. Eşzamanlı gerçekleşecek 3 eylem İsveç Güvenlik Servisi'nce çökertildikten sonra kaçak durumuna düşen ỉbbe, örgüt propagandasına maruz bıraktığı öğrencilerden Kerima'yı birlikte intihar eylemi yapma yalanıla kandırmış; bir konser alanında Kerima'nın üzerine yerleştirdiği bombayı uzaktan kumanda ile patlatmıştır. Bu sahne aynı zamanda dizinin finalini oluşturmaktadır.

\subsubsection{Müslüman Karakterler ve Temsil}

Daha önce belirtildiği gibi dizide İslam yalnızca olumsuzluklar üzerinden temsil edilmektedir. Dizideki Müslüman yahut Türk, Arap, Boşnak gibi köken olarak Müslüman karakterlerin temsilinde ise daha ilginç bir durum göze çarpmaktadır. Dizi, istisnasız olarak oluşturduğu tüm temsillerle Batılı değerleri sahiplenmiş, İslami bir yaşam tarzını bütünüyle terk etmiş seküler göçmen kimliğiyle ışiD’e destek verecek kadar radikalleşmiş dindar göçmen kimliği arasında bir tercih yapma zorunluluğunu vurgulamaktadır. Dizinin inşa ettiği bu iki kimlik, Müslüman yahut köken olarak Müslüman karakterlerin temsilleri çözümlenerek ortaya konulabilir.

\subsubsection{Dindar Kimliğin Temsili}

Ibbe (Ibrahim Haddad): Dizide dindar bir karakter olarak resmedilen ibbe, Jarva Gard adlı lisede öğretmen asistanlığı yapmaktadır. İbbe, dizinin henüz başında entelektüel ve normal/makul bir karakter olarak resmedilir. Kısa bir süre sonra seyirciye gerçek kimliği gösterilen İbrahim Haddad, profesyonel basketbol oynamak amacıyla Mısır'a gitmiş gibi gözükerek ışi̇D'e katılmak üzere Rakka'ya gitmiş, sonrasında ise İsveç'te düzenlenecek terör eylemlerini koordine etmek üzere İsveç'e geri gönderilmiş son derece profesyonel 
ve soğukkanlı bir teröristtir. ỉbbe, gerek içerisinde bulundukları boşluktan, gerek kendisine duydukları hayranlıktan gerekse de yaşadıkları ailevi problemlerden yararlanarak çalıştığı lisedeki kız öğrencilerden Kerima, Suleika ve Lisha'yı örgüte katılmaya ikna etmiștir. Öte yandan eylemlerin başarıyla gerçekleșmesi için çeşitli sahte kimlikler kullanarak birçok ayarlama yapmış, Jakob ve Emil kardeşleri de saldırıları gerçekleştirmek için eğitmiştir. Planları başarısız olduğunda ise Kerima'yı üzerine yerleştirdiği bomba düzeneği ile bir konser alanına göndermiş ve uzaktan kumanda ile patlatmıştır. Dizide dindar bir karakter olarak temsil edilen ibbe, hedeflerini gerçekleştirmek için her türlü yalana, manipülasyona ve kötülüğe başvuran eli kanlı bir teröristtir.

Suleika Wasem: İbbe tarafından kandırılarak Suriye'ye gönderilmeye çalışılan üç kızdan biri olan Suleika 15 yaşındadır. Dizinin başlarında seküler bir görüntüyle karşımıza çıkan Suleika, İsrail-Filistin meselesiyle ilgili yaptığı okumalardan sonra radikalleşmeye başlamıştır. Bununla birlikte Suleika, dünyanın en ırkçı ülkelerinden biri olduğunu düşündüğü için İsveç'e aidiyet hissetmemektedir ve bu durumdan faydalanmak isteyen ỉbbe tarafından örgüt propagandasına maruz bırakılmaktadır. Radikalleştikten sonra başörtüsü takmaya başlayan Suleika, neredeyse İslam düşmanı olarak gösterilen babası tarafından baskı altında tutulmaktadır. Kardeşi Lisha ve en yakın arkadaşı Kerima ile birlikte Rakka'ya gitmek üzere yola çıkan Suleika, sınırda yakalanmış ve ülkesi İsveç'e götürülmüştür. Suleika, dindarlaştıkça radikalleşen ve sonunda IşiD’i destekleyecek kadar ileri giden bir karakterdir.

Lisha Wasem: Suleika'nın 13 yaşındaki kız kardeşidir. Ablasıyla birlikte seküler bir ailede büyüyen Lisha, İslam'a dair neredeyse hiçbir şey bilmemektedir. Tıpkı Suleika ve Kerima gibi İbbe tarafından kandırılan Lisha, ikisinden farklı olarak sınırda yakalanmamış ve Rakka'ya kaçırılmıştır. Rakka'dayken kendisine kol kanat geren Pervin'i, kendisini de alarak İsveç'e kaçmaya çalışırken ışiD militanlarına ihbar etmiş ve öldürülmesine neden olmuştur. Lisha da dine ilgi gösterdikten sonra radikalleşip IşiD’e katılan bir diğer karakterdir.

Kerima: Suleika ve Lisha'yla birlikte Jarva Gard adlı lisede öğrenci olan Kerima, dizinin başında son derece seküler olarak resmedilen bir karakterdir. Alkolik babasının şiddetinden kaçtığı bir gece kendisini takip eden Ibbe tarafından kurtarılmış ve bir süre onun evinde yaşamaya başlamıştır. En yakın arkadaşı Suleika gibi İbbe'nin propagandasıyla radikalleşen Kerima, iki arkadaşıyla birlikte Rakka'ya gitmeye çalışırken Türkiye'de yakalanmıştır. Duygusal olarak dengesiz bir karakter olan Kerima, sınırda yakalanıp İsveç'e götürüldükten sonra intihar girişiminde bulunmuş ve başarısız olmuştur. Lisha gibi dini bilgisi oldukça zayıf olan Kerima, aynı zamanda saf bir karakter olarak resmedilmiştir. İsveç polisinin elinden kaçtıktan sonra ibbe tarafından ortak bir intihar eylemi yapacaklarmış gibi kandırılan Kerima, gönderildiği konser alanında İbbe tarafından üzerindeki bombanın patlatılmasıyla hayatını kaybetmiştir.

Pervin: Öncesinde normal bir yaşantısı olduğu söylenen Pervin, dindarlaştıktan sonra radikalleșmiş ve Rakka'ya giderek ışiD’e katılmıştır. Burada aradığını bulamayan Pervin pişman olmuş ve bebeğiyle birlikte ülkesine dönüşün yollarını aramaya başlamıştır. İsveç Güvenlik Servisi’nden Fatima Zukic'le iletişime geçen Pervin, Rakka'dan kurtarılmak karşılığında örgütün planladığı saldırıya dair bilgilere ulaşıp Zukic'e aktarmaktadır. Dizinin son bölümünde Zukic'in de yardımıyla örgütten kaçmaya çalışan Pervin, Lisha'nın ihbarı sonucu İsveçli örgüt üyelerinden Omar Al Soudani tarafından öldürülmüştür.

Husam: Pervin'in kocası olan Husam, Arap asıllı bir İsveçlidir. Normalde dinden uzak, seküler bir tipken bir yer altı mescidine gitmeye bașlayıp birkaç hafta içinde hızla radikalleșmiș ve ışid’e katılmıștır. Psikolojik olarak güçsüz bir karakter olan Husam, örgütle birlikteyken yaptığı bazı eylemlerden vicdan azabı duysa da yaptıklarının dinen doğru şeyler olduğuna kendini inandırmaya çalışmaktadır. Hem psikolojik sorunlarından hem de ölüm korkusundan dolayı cephede savaşmak istemese de güçsüz biri olarak görünmek istemediği için uzunca bir süre hem kendine hem de etraftakilere bu durumu itiraf edememiştir. Husam, aynı zamanda İsveç'te gerçekleştirilecek terör saldırılarının planlayıcılarındandır. Omar Al Soudani tarafından intihar saldırısı düzenlemeye zorlanan Husam, ölmek istemediği için karısıla beraber ülkesine dönme fikrine ikna olmuştur. Dönüş yolunda karısını kaybetse de kendisi Rakka'dan çıkmayı başarmıştır. Husam da dindarlaşmaya başladıktan sonra radikalleşen bir diğer karakterdir.

Jakob ve Emil Johannison: İbbe tarafından İsveç’te saldırı düzenlemek üzere eğitilen Jakob ve Emil, sonradan Müslüman olmuş iki kardeştir. Sabıkalı bir suçlu olan abi Jakob hapiste Müslüman olmuş ardından kardeşi Emil de ona katılmıştır. Her iki karakter de duygusal olarak oldukça dengesiz bir şekilde resmedilmiştir. Annesinden nefret ettiği bilinen Jakob, saldırıdan önce evine giderek onu öldürmüştür. íkili saldırıyı gerçekleştiremeden güvenlik güçlerince olay yerinde öldürülmüştür.

Omar Al Soudani: Hakkında fazlaca bilgi verilmeyen Soudani, oldukça dindar bir karakter olup, İsveç'te gerçekleştirilecek saldırıyı planlayan ekibin başındadır. Örgütten kaçmaya çalışan Pervin’i öldürmüş, hemen arkasından Fatima Zukic tarafından öldürülmüştür. 
Ahmed: Rakka'daki İsveçlilerden olan Ahmed, Müslüman olmadan önce tecavüz, hırsızlık, cinayete teşebbüs gibi suçlardan sabıkası olan bir suçludur. Örgüte katıldıktan sonra da kadınlara olan düşkünlüğü azalmamıştır. Hüsam'ın karısı Pervin'le birlikte olmak istemektedir. Hüsam hava saldırısında yaralandıktan sonra evine gidip Pervin'e tecavüz etmiş, ardından Pervin tarafından öldürülerek cesedi kuyuya atılmıştır.

Abu Jibril: İsveçli örgüt militanlarının baba gibi gördüğü, İsveç’te yaşayan terör destekçisi bir “alim”dir. Saldırılardan 2 yıl kadar önce İsveç Güvenlik Servisi Ortadoğu Sorumlusu Nadir El Shahrani’ye çalışmaya başlayan Abu Jibril, sağladığı istihbaratla saldırının önlenmesini sağlamıştır.

Ghaddah: İbbe ile birlikte IşiD için çalışan Ghaddah, İsveç’te yaşayan kadın bir teröristtir. ibbe'nin ağına düşürdüğü kızlarla ilgilenip örgüte katılmaları için Rakka'ya götürmektedir.

\subsubsection{Seküler Kimliğin Temsili}

Süleyman Wasem: Suleika ve Lisha'nın babası olan Süleyman, Arap asıllı bir göçmendir. Ait olduğu kültürden nefret eden Süleyman, bütünüyle asimile olmuş ve Batılı yaşam tarzını sahiplenmiştir. Öyle ki kültürlerini korudukları için kendisi gibi Arap olan eşinin akrabalarından hazzetmemektedir.

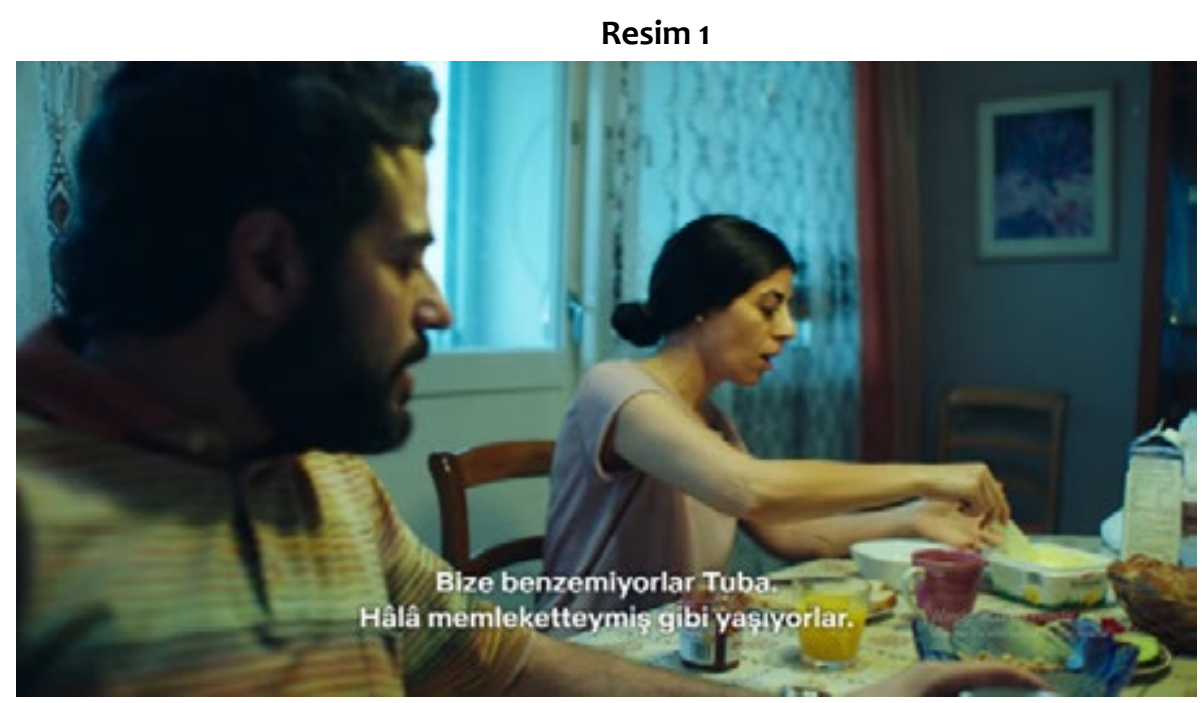

Dizide, kültürünü reddetmeyen göçmen temsili de son derece oryantalist bir yaklaşımla inşa edilmiştir. İstemeyerek de olsa eșinin akrabalarının davetine katılan Süleyman ile ev sahibi arasında geçen konuşma söz konusu oryantalist yaklaşımı belirginleştirmektedir:

Ev sahibi: Süleyman, biraz konuşalım. Iki kızın var değil mi?

Süleyman: Evet. Suleika 15, Lisha 13 yaşında. (Gülerek) Hep yaramazlık yapıyorlar.

Ev sahibi: (Ciddi bir ses tonuyla) Erkek adam çocuklarını hep dövmelidir.

Süleyman aynı zamanda neredeyse İslam düşmanı bir karakter olarak resmedilmektedir. Kızlarının dindarlaşmasından son derece rahatsız olan Süleyman, bu konuda kızının başörtüsünü güç kullanarak çıkaracak kadar ileriye gidebilmektedir. 


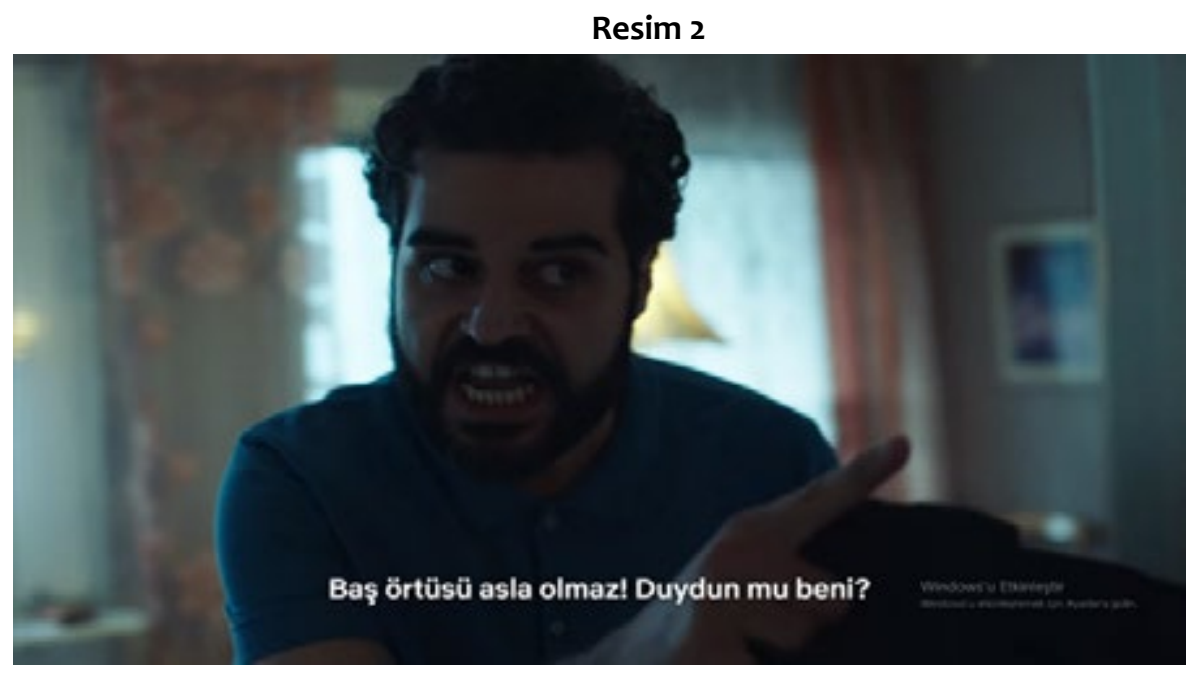

Burada Süleyman'la ilgili kayda değer nokta, kızlarının radikalleşmesinden değil dindarlaşmasından da rahatsız olmasıdır. Suleika'nın ışiD’e olan meyli babası tarafından bilinmezken yalnızca seküler değerleri bırakıp dine uygun bir yaşam sürmeye başlaması bile Süleyman'ı çileden çıkarmaya yetmiştir. Örneğin kızına neden basketbol oynamaya gitmediğini soran Süleyman, "Haram.” cevabını aldıktan sonra karısının yanına giderek, "Haram? Kendi evimde bu kelimeyi duymam mı gerek?.... Dini nedenlerle basketbolu bırakması sence normal bir şey mi?” şeklinde sitem eder. Kızının dini gerekçelerle "seküler” yaşam tarzından uzaklaşması onu rahatsız etmektedir. Söz konusu sahnenin devamında eşi Tuba endişeli bir sesle Süleyman’ı çağırır ve Suleika'nın bilgisayarında bulunan IşiD videosunu gösterir. Bu noktada izleyiciye verilen mesaj, dindarlaşmanın radikalleşmeye yol açacağıdır. Dizi boyunca süren "ya seküler ya radikal” şeklindeki ikilik bu sahnede oldukça somutlaşmaktadır.

Dindarlaşmanın radikalleşmeyle sonuçlanacağı mesajının açık şekilde verildiği bir diğer sahne ise kızı Suleika'nın IşiD'e katılmasını engellemek isteyen Süleyman'ın, bu konuda deneyimli olan Khalid'le yaptıkları konuşmada verilir. Somali'de Eş-Şebab için savaşırken ölen oğlundan bahseden Khalid, oğlunun yaşadığı olumsuz dönüşümün suçlusu olarak İslam'ı göstermektedir: "Spanga lisesinde okumuştu. İyi bir İsveç lisesidir. Sosyal Demokrat Parti Gençlik Kolu üyesiydi. Avukat olacaktı. Çok güçlüydü. Benden çok daha güçlü. On yedi yaşında tüm aileyi parmaklarında oynatırdı. Sonra birden İslam çıktı.” Görüleceği üzere seküler Müslüman göçmen kimliğinin karşısına bir kez daha radikal dindar kimliği yerleştirilmiş; dindarlaşma radikalleşmeyle eşdeğer tutulmuştur.

Tuba Wasem: Süleyman'ın karısı olan Tuba, kocası gibi İslam’a yönelik bir düşmanlık içerisinde bulunmamakla birlikte, seküler bir yaşam tarzına sahip bir karakter olarak resmedilmektedir. Kocası kadar kendi kültürüne yabancılaşmamış olsa da içerisinde yaşadığı toplumun değerleri ve yaşam tarzıyla uyumlu görünmektedir.

Fatima Zukic: Annesiyle birlikte 5 yaşında Bosna'dan İsveç'e kaçan Fatima, İsveç Güvenlik Servisi Ortadoğu Bölümü’nde çalışmaktadır. Köken olarak Müslüman olan Fatima son derece seküler bir karakterdir. İş arkadaşı olan evli bir adamla ilişki yaşayacak, uyuşturucu kullanacak kadar İslam'dan uzak bir yaşam tarzına sahiptir. İş hayatında da başarısız bir görüntü çizen Fatima, kendisine ulaşan Pervin'in vereceği bilgilerle hem terör saldırısını engellemeye hem de kariyerini kurtarmaya çalışmaktadır. Kanında uyuşturucu izine rastlandığı ve amirlerinin emirlerine itaatsizlik ettiği gerekçesiyle açığa alınan Fatima, gayri resmi olarak davanın peşini bırakmamış ve Pervin'e yetkilerinin elinden alındığını söylememiştir. Süreç içerisinde amiri Nadir'in teröristlerle birlikte çalıştığından şüphelenmiş, yaptığı yasadışı işler yüzünden gözaltına alınmışken Nadir'in saldırıları önlemesiyle yanıldığını anlamıştır. Fatima, bundan dolayı zaman zaman vicdan azabı duysa da Pervin'i defalarca istediklerini yapmaması halinde Rakka'dan kurtarmamakla tehdit etmiştir. Pervin'den sürekli daha fazlasını istemiș, kurtarma operasyonunu ertelemiştir. Verdiği sözü yerine getirmek için kişisel kontağını kullanarak Rakka'ya gitse de Pervin'in öldürülmesine engel olamamıştır.

Nadir El Shahrani: İsveç Güvenlik Servisi Ortadoğu Bölümü sorumlusu Nadir El Shahrani, köken olarak Müslüman olmakla birlikte hakkında çok fazla bilgiye yer verilmeyen bir karakterdir. Karakterin dine veya dindarlığa dair herhangi bir temsille yer bulmayışı, görece seküler bir karakter olduğunu düşündürmektedir. 


\section{Sonuç}

Batılı toplumlarda giderek histerik bir hal alan İslamofobinin üretilmesi ve yayılmasında medyanın etkisi son derece fazladır. Özellikle sinema filmleri ve dizilerde kullanılan İslamofobik söylem, bu platformların sahip oldukları güç nedeniyle oldukça tehlikeli sonuçlar doğurabilmektedir. Daha önce değinildiği gibi medyada İslamofobik söylem her zaman açık bir şekilde yer bulmayabilir. Bu noktada medya metinlerinin arka planında saklı olan ideolojik inşanın ortaya açığa çıkarılması için, metne içkin söylemlerin çözümlenmesi gerekmektedir. İsveç yapımı Kalifat dizisindeki Müslüman temsillerinin incelendiği bu çalışmada da söz konusu inşa süreçlerinin ortaya çıkarılabilmesi için söylem analizi yöntemine başvurulmuştur.

Çalışmanın sonucuna göre, dizide Müslüman kimliği iki aşırı uçta temsil edilmiştir. Dizide dindar olarak temsil edilen karakterlerin bütünü IşiD’le ilişkilidir. Dindar olarak gösterildiği halde IşíD’i desteklemeyen, "makul” bir dindar kimliğiyle hayatını sürdüren hiçbir karakter yoktur. Sonradan Müslüman olan karakterler de köken olarak Müslüman oldukları halde dine sonradan yönelen karakterler de istisnasız olarak IŞiD’e katılmış ya da katılmaya çalışmıştır. Dindarlaşmanın radikalleşmeyle sonuçlanacağı mesajı, özellikle dindar karakterlerin dönüşümleri üzerinden birçok kez verilmiştir. Buna paralel olarak dizide IşiD’i desteklemeyen Müslüman kökenli karakterlerin tamamı son derece seküler yaşamlarla temsil edilmişlerdir. Kızının başörtüsünü şiddet kullanarak açacak kadar İslam'a karşı olan baba, eşi gibi İslam'dan nefret etmese de seküler bir yaşam tarzına sahip olan anne, evli bir adamla ilişki yaşayıp uyuşturucu kullanan dedektif, kızına şiddet uygulayan alkolik baba, dizinin dindar-radikal Müslüman kimliğine karşı konumlandırdığı karakterlerdir.

Görüleceği üzere Kalifat dizisinde sıradan bir dindar Müslüman’a yer yoktur. Dizinin tasavvurundaki İsveç'te Müslüman bir göçmen ya dindarlașıp terörist olur ya da kendi kültürünü ve değerlerini bir kenara bırakarak seküler bir yaşam sürer. Bu anlamda Kalifat dizisi iki ucun arasında kalan ve halen İslam dünyasında ana akımı teşkil eden “makul”ü öldürmüş; dindarlığı terörizmle eşdeğer şekilde sunmuş ve böylelikle Müslümanlara yönelik saldırıların giderek arttığı İsveç'te İslamofobinin yeniden üretilmesine aracılık etmiştir.

Nitel bir yöntem kullanılarak tekil bir örneğin ele alındığı bu çalışma, doğası gereği herhangi bir genellenebilirlik iddiası taşımamaktadır. Bununla birlikte İslamofobi’nin yükselişe geçtiği ülkelerde, görsel medyada Müslüman karakterlerin temsil ediliş biçimleriyle bu ülkelerde İslamofobi'nin yükselişte olması arasındaki olası ilişkinin araştırılmasının literatüre büyük bir katkı sağlayacağı düşünülmektedir. Ek olarak, diğer Avrupa ülkelerindeki görsel medyada da Müslüman karakterlerin yalnızca radikal-seküler ikiliği üzerinden mi yoksa gerçeğe uygun biçimde "makul” temsillere de yer verilerek mi temsil edildiklerinin araştırılması, sonraki çalışmalar için bir öneri olarak ortaya konulabilir.

\section{Son Notlar}

${ }^{1}$ Avrupa'da yükselen aşırı sağ ve İslamofobi ile ilgili detaylı bilgi için bkz. Bayraklı, E., ve Hafez, F. (Dü.). (2020). European Islamophobia Report 2019. SETA: İstanbul.

${ }^{2}$ Konuyla ilgili örnekler için bkz. a: https://www.dailysabah.com/world/europe/far-right-french-politician-le-pen-calls-for-nationwide-headscarf-ban

b: https://www.moroccoworldnews.com/2021/04/339802/geert-wilders-attacks-islam-muslims-holy-month-of-ramadan c: https://tr.sputniknews.com/20200830/isvecte-asiri-sagci-grup-kuran-i-kerim-yakti-sokaklar-karisti-1042749792.html

\section{Kaynakça}

Abdullahi, M. (2016). Forgotten women: The impact of Islamophobia on Muslim women in Sweden. European Network against Racism, Brüksel.

Aguayo, M. (2009). Representations of Muslim bodies in the Kingdom: Deconstructing discourses in Hollywood. Global Media Journal, 2(2), 41-56.

Ahmed, S., and Matthes, J. (2017). Media representation of Muslims and Islam from 2000 to 2015: A meta-analysis. The International Communication Gazette, 79(3), 219-244.

Akgül Durakçay, F. ve Güneş Gülal, A. G. (2017). Fransa'da yükselen nefret söylemi ve nefret suçu: Tematik bir çözümleme. Avrasya Sosyal ve Ekonomi Araștırmaları Dergis, 5(10), 126-145.

Altuntas, A. (2019, Nisan 18). Half of internet hate crimes target Muslims in Sweden. https://www.aa.com.tr/en/ europe/half-of-internet-hate-crimes-target-muslims-in-sweden/1457252 adresinden alındı

Arvas, N. (2016). Hollywood sinemasında öteki sorunsalı bağlamında Müslüman kimlik temsili. https://tez.yok. gov.tr/UlusalTezMerkezi/ adresinden alındı

Aydın, M. Z. ve Yardım, M. (2007). Belçikaıda İslamofobi. K. Canatan ve Ö. Hıdır (Ed.) içinde, Batı Dünyasında islamofobi ve Anti-islamizm (s. 373-403). Ankara: Eski Yeni Yayınları. 
Bayraklı, E. (2020). Islamophobia in Germany: National report 2019. E. Bayraklı, and F. Hafez (Ed.) içinde, European Islamophobia Report 2020 (s. 329-356). İstanbul: SETA.

Bayraklı, E., and Hafez, F. (2018). The state of Islamophobia in Europe. E. Bayraklı, and F. Hafez (Ed.) içinde, European Islamophobia Report 2017 (s. 7-31). İstanbul: SETA.

Bayraklı, E., \& Hafez, F. (2020). The state of Islamophobia in Europe in 2019. E. Bayraklı, and F. Hafez (Dü) içinde, European Islamophobia Report 2020 (s. 7-31). İstanbul: SETA.

Buehler, A. F. (2014). İslamofobi: Batı'nın “karanlık tarafı”nın bir yansıması. Ankara Üniversitesi Illahiyat Fakültesi Dergisi, 55(1), 123-140.

Burr, V. (2012). Sosyal inşacılık. Ankara: Nobel.

Cervi, L., Tejedor, S., and Gracia, M. (2021). What kind of Islamophobia? Representation of Muslims and Islam in Italian and Spanish media. Religions, 12(6), 427.

Çağlar, Ş. (tarih yok). Medya analiz yöntemleri. İstanbul Üniversitesi Açık ve Uzaktan Eğitim Fakültesi.

Çelik, H. ve Ekşi, H. (2008). Söylem analizi. Marmara Üniversitesi Atatürk Eğitim Fakültesi Eğitim Bilimleri Dergisi, 27(27), 99-117.

Demir, T. (2020). Amerikan Hollywood sinemasında İslamofobi: Keskin Nişancı film örneği incelemesi. https:// tez.yok.gov.tr/UlusalTezMerkezi/ adresinden alındı

Deniz, Ş. (2010). Türkiye'de yazılı basında kadınların siyasal temsili: 3 Kasım 2002 ve 22 Temmuz 2007 Genel Seçimleri. Journal of Yaşar University, 5(19), 3199-3220.

Ekinci, B. T. (2014). ARGO filmi bağlamında Hollywood sinemasında söylem ve yeni oryantalizm. Atatürk iletişim Dergisi(6), 51-66.

European Monitoring Centre on Racism and Xenophobia. (2006). Muslims in the European Union: Discrimination and Islamophobia. EUMC.

Fatima, S. (2016). Muslim in movies: The Hollywood construction. Pakistan Journal of Society, Education and Language (PJSEL), 2(1), 54-75.

Gardell, M., and Muftee, M. (2018). Islamophobia in Sweden: National report 2017. E. Bayraklı, and F. Hafez (Ed.) içinde, European Islamophobia Report 2017 (s. 617-646). İstanbul: SETA.

Göker, G. ve Keskin, S. (2015). Haber medyası ve mülteciler: Suriyeli mültecilerin Türk yazılı basınındaki temsili. iletişim Kuram ve Araştırma Dergisi(41), 229-256.

Gölcü, A. ve Aydın Varol, F. B. (2018). Yükselen bir trend olarak İslamofobi endüstrisi: Amerikan medyasına yönelik araştırmaların bir panoraması. Medya ve Din Araştırmaları Dergisi (MEDIAD), 1(1), 73-88.

Gölcü, A. ve Çuhadar, M. (2017). Batı toplumlarında İslamofobisnin üretilmesinde medyanın rolü. Ombudsman Akademik(7), 71-99.

Hall , S. (2003). Introduction. S. Hall (Ed.) içinde, Representation (s. 1-12). London: Sage Publications.

Halliday, F. (1999). 'Islamophobia’ reconsidered. Ethnic and Racial Studies, 22(5), 892-902.

Hussain, D. (2015, Ocak 12). The rise of Islamophobia and the far-right in Sweden. https://5pillarsuk. com/2015/01/12/the-rise-of-islamophobia-and-the-far-right-in-sweden/ adresinden alındı

Kabir, N. (2006). Representation of Islam and Muslims in the Australian media, 2001-2005. Journal of Muslim Minority Affairs, 26(3), 313-328.

Karaduman, S. (2017). Eleştirel söylem çözümlemesinin eleştirel haber araştırmalarına katkısı ve sunduğu perspektif. Maltepe Üniversitesi Illetişim Fakültesi Dergisi, 4(2), 31-46.

Kiran, U., Qamar, A., Adnan, M., and Youssef, E. Y. (2021). Muslims depiction in Hollywood movies: A qualitative study. PalArch's Journal of Archaeology of Egypt/Egyptology, 18(8), 1126-1136.

López, F. B. (2011). Towards a definition of Islamophobia: Approximations of the early twentieth century. Ethnic and Racial Studies, 34(4), 556-573.

Oumlil, K. (2009). Arabs and Muslims in Hollywood: Breaking down The Siege. M. Guggisberg, and D. Weir (Ed.) içinde, Understanding Violence: Context and Portrayals (s. 15-24). Oxford: Inter-Disciplinary Press. 
Özer, Ö. (2011). Haber söylem ideoloji: Eleştirel haber çözümlemeleri. Konya: Literatürk Yayınları.

Polat, H. (2018). Geleneksel medyada temsil sorunu: Alternatif bir mecra olarak yeni medya. Karadeniz Uluslararası Bilimsel Dergi(38), 45-60.

Posos Devrani, A. E. (2017). Medyada “öteki”nin temsili: Etnik komediler. Gümüşhane Üniversitesi Iletişim Fakültesi Elektronik Dergisi, 5(2), 926-949.

Reid, J. (2015). The age of sympathy: Re-examining discourses of Muslim terrorism in Hollywood beyond the'pre-' and 'post 9/11'dichotomy. PLATFORM: Journal of Media \& Communication, 6(2), 95-107.

Reiermann, J., and Andersen, T. (2019, Ekim 21). Hver fierde dansker: Muslimer skal ud af Danmark. https:// www.mm.dk/artikel/hver-fjerde-dansker-muslimer-skal-ud-af-danmark adresinden alındı

Riots in Sweden after far-right activists burn copy of Quran. (2020, 29 Ağustos). https://www.aljazeera.com/ news/2020/8/29/riots-in-sweden-after-far-right-activists-burn-copy-of-quran adresinden alındı

Sarı, E. ve Klein, L. (2020). Fransız popüler sinemasında Fransız Müslümanların temsili ve kültürlerarasılı̆ı̆ın inşası. Intermedia International e-Journal, 7(12), 217-237.

Sevimli, M. A. ve Kasım, M. (2019). Alısıllık tanımlamaların gölgesinde İslami inancın Batı Sineması'nda yeniden sunumu: Taken 2. Akdeniz Üniversitesi İletişim Fakültesi Dergisi (AKiL), 2019, 340-357.

Shaheen, J. G. (2003). Reel bad Arabs: How Hollywood vilifies a people. The Annals of the American Academy of Political and Social Science, 588, 171-193.

Söğüt, F. (2019). Yeni medya ve temsil: Internet gazeteciliğinde cinsiyet kimliklerinin sunumu. Akdeniz Üniversitesi iletişim Fakültesi Dergisi (AKiL)(31), 212-231.

Temel, M. (2019). Türkiye'de medya ve İslamofobi araştırmaları. Medya ve Din Araştırmaları Dergisi (MEDiAD), 2(1), 93-121.

Temel, M. ve Koçak, Ö. F. (2020). İslam karşıtı söylemlerin Avrupa medyasındaki izleri. Medya ve Din Araştırmaları Dergisi (MEDIAD), 3(2), 181-196.

The Runnymede Trust. (1997). Islamophobia a challenge for us all. https://www.runnymedetrust.org/companies/17/74/Islamop adresinden alındı

Tomson, D. L. (2020). The rise of Sweden democrats: Islam, populism and the end of Swedish exceptionalism. https://www.brookings.edu/research/the-rise-of-sweden-democrats-and-the-end-of-swedish-exceptionalism/ adresinden alındı

Türkdoğan, O. ve Gökçe, O. (2015). Sosyal bilimlerde araştırma yöntemi. Konya: Çizgi Kitabevi Yayınları.

Türkmen, M. Y. ve Özçınar, M. (2020). 11 Eylül sonrası Hollywood sinemasında İslamofobinin yeniden üretimi. Erciyes iletişim Dergis, 7(2), 1321-1343.

Uluç, G. ve Küngerü, A. (2018). Sinemada Arapların temsiline bir örnek: "Keskin Nişancı” filmi. Akademik Bakış Uluslararası Hakemli Sosyal Bilimler Dergisi(68), 1-13.

van Dijk, T. A. (1997). The study of discourse. T. A. van Dijk (Ed.) içinde, Discourse as Structure and Process (s. 1-34). London: SAGE Publications.

van Dijk, T. A. (2006). Ideology and discourse analysis. Journal of Political Ideologies, 11(2), 115-140.

Varol, S. F. (2014). Medyada yer alan temsillerin kimlik edinme sürecindeki rolü. The Journal of Academic Social Science Studies(26), 301-313.

Willig, C. (1999). Introduction: Making a difference. C. Willig (Dü.) içinde, Applied Discourse Analysis: Social and Psychological Interventions (s. 1-21). Buckingham: Open University Press.

Yardım, M. (2017). Aşırı sağ ve çokkültürlülük: Avrupa'da ötekileştirilen "göçmenler”. Akademik Incelemeler Dergisi, 12(2), 217-234.

Yel, A. M. (2018). Medya ve sinemada temsil edilme biçimleriyle İslam karşıtlığı. Medya ve Din Araștırmaları Dergisi (MEDIAD), 1(1), 5-16. 


\title{
Killing the "Average": Representation of Muslim Identity in Kalifat
}

\author{
Şükrü BALCI \\ Muhammet Emin Çifçi
}

\section{Extended Abstract}

With the rise of the far right in the United States and Europe, Islamophobia has also gained momentum. The concept of Islamophobia is defined as "unfounded hostility towards Islam" in the report of The Runnymede Trust (1997, s. 4), a large-scale study on Islamophobia in England. Islamophobia, which causes discrimination and hate speech against Muslims, is not limited to psychological violence, but also causes terrorist acts in which many Muslims are killed, as in the example of Christchurch attack. Along with many factors, the media has been influential in the strengthening of Islamophobia. The Western media, which associates Islam and Muslims with terrorism especially in the news after September 11, is considered the most effective tool in the production of Islamophobia (Gölcü \& Çuhadar, 2017).

Buehler (2014) states that the Western media has been trying to establish a relationship between Islam and terrorism. According to him, while in any event involving a Muslim perpetrator, the perpetrator's religious identity is brought to the fore; no relationship between the religion and followers of the religion is established with the violent acts committed by people from different religions and geographies. Similarly, Ahmed and Matthes (2017), in their meta-analysis of 345 articles published between 2000 and 2015, found that Islam was associated with violence in the Western media and Muslims were represented through negativity. According to Kabir (2006), the media "effectively demonizes all Muslim people" through their representations based on Islamic militancy (s. 326). This "demonization" of Muslims has justified attacks against them, as in the examples of Afghanistan and Iraq (Oumlil, 2009).

However, the production of Islamophobia is not limited to the news media, other media products are also used for this purpose (Gölcü \& Çuhadar, 2017). The role played by Hollywood cinema in the reproduction and circulation of Islamophobia has been the subject of many studies. Shaheen (2003), examined over 900 Hollywood productions produced over a 100-year period and found that almost all of these productions portrayed Arabs in bad forms such as "heartless", "brutal", "uncivilized" and only five percent of productions featured a normal Arab character.

The role that movies and TV series play in the identity formation processes of individuals makes the problem of representation a vital issue for these platforms. While media organizations highlight a certain social group according to the identity policies shaped by the organizations' political or economic interests, they can overlook a different group or misrepresent them (Varol, 2014). The media shapes the perception that people have towards certain social groups with their representations, and these perceptions become "social reality" over time (Deniz, 2010). Through representation, certain patterns are presented to people and how the audience will see themselves, others and events is shaped (Söğüt, 2019). Thus, the media is effective in defining "us" and "others" in the identity formation processes of individuals (Posos Devrani, 2017).

The TV series called Kalifat, which is the subject of this study, is a Swedish production. Sweden is a country where Muslims are subjected to Islamophobic hate crimes, and the Christian Democrats, an anti-Muslim far-right party, are the third largest party in its parliament. For this reason, the issue of how Muslim identity is represented in a Swedish-made series in which Muslim characters are at the center, is of great importance. In this study, that focuses on how Muslim identity is represented in the Swedish TV series Kalifat, the method of discourse analysis is used to reveal how Muslim identity is constructed. According to the results of the study, Muslim identity was represented at two extremes in the series. All of the characters represented as religious in the series are related to ISIS. There is no character who, although portrayed as religious, did not support ISIS and lives with an "average" religious identity. The characters who later converted to Islam, and the ones who became religious despite being Muslim in origin, also joined or tried to join ISIS without exception. The message that religiousness will result in radicalization has been given many 
times, especially through the transformations of religious characters. Parallel to this, all of the Muslim-origin characters who do not support ISIS in the series are represented by living extremely secular lives. The father, who is so anti-Islam that takes his daughter's hijab off by using violence; the mother, who has a secular lifestyle even though she does not hate Islam like her husband; the detective who has a relationship with a married man and uses drugs; and the alcoholic father who abuses his daughter are the characters that the series positions against the religious-radical Muslim identity.

As it is seen, there is no place for an ordinary devout Muslim in the Kalifat series. According to the vision of the series, a Muslim immigrant in Sweden either becomes religious and a terrorist or leads a secular life by leaving his own culture and values aside. In this sense, the Kalifat series killed the "average" who is in between the two extremes and still constitutes the mainstream in the Islamic world; presented religiosity as equivalent to terrorism and thus, mediated the reproduction of Islamophobia in Sweden.

\section{Araştırmacıların Katkı Oranı Beyanı/ Contribution of Authors}

Yazarların çalışmadaki katkı oranları eşittir.

The authors' contribution rates in the study are equal.

$* * * * * * * *$

\section{Çıkar Çatışması Beyanı / Conflict of Interest}

Çalışma kapsamında herhangi bir kurum veya kişi ile çıkar çatışması bulunmamaktadır.

There is no conflict of interest with any institution or person within the scope of the study.

$* * * * * * * *$

Intihal Politikası Beyanı / Plagiarism Policy

Bu makale iThenticate yazılımıyla taranmıştır. İntihal tespit edilmemiştir.

This article has been scanned by iThenticate. No plagiarism was detected.

$* * * * * * * *$

Bilimsel Araştırma ve Yayın Etiği Beyanı / Scientific Research and Publication Ethics Statement

Bu çalışmada "Yükseköğretim Kurumları Bilimsel Araştırma ve Yayın Etiği Yönergesi” kapsamında uyulması belirtilen kurallara uyulmuştur.

In this study, the rules stated in the "Higher Education Institutions Scientific Research and Publication Ethics Directive" were followed. 